\title{
Legal aspect of the implementation of the UN sustainable development goals in the field of environmental management in Russia
}

\author{
Maria Mukhlynina ${ }^{1 *}$, and Natalia Vedysheva ${ }^{2}$ \\ ${ }^{1}$ Institute of State and Law of the Russian Academy of Sciences (ISL RAS), Moscow, Russia \\ ${ }^{2}$ Kutafin Moscow State Law University, Moscow, Russia
}

\begin{abstract}
Based on the analysis of strategic documents and other regulatory legal acts, the authors of the article attempt to consider a number of issues of the state environmental policy of the Russian Federation designed to contribute to the implementation of the UN sustainable development goals in the field of environmental management. The opinion is expressed that a successful environmental policy in the implementation of the UN sustainable development goals is possible only with a systematic approach to the implementation of environmental legislation. The authors analyze the measures, undertaken by the Russian Federation in the use and protection of forests and water resources, in terms of their effectiveness and draw a number of conclusions.
\end{abstract}

\section{Introduction}

New global challenges of our time forced the outdated traditional model of the economy, which could no longer resist these challenges, to change. Russia, like many other developed countries of the world, is now undergoing a difficult process of reorienting to build a new model in accordance with the Sustainable Development Goals. On September 25, 2015, UN member states adopted 17 Sustainable Development Goals (SDGs) until 2030 and 169 tasks which the countries of the world must fulfill in this period. Such a reorientation of the country requires changes both at the level of the regulatory legal base, and at the organizational and managerial level in all spheres of the country's life.

In general, researchers differently define the concept of "public policy". For example, E.V. Luneva notes that public policy is "a system of values, ideas and views that reflect the direction of state activity toward obtaining a predetermined result in any sphere of public relations" [1]. State regulation of forest and water relations during the reform period is of great importance. Especially debatable by theorists and practitioners is the issue of expanding the scope of private regulation in the field of forest relations.

Let us dwell in more detail on two natural resources that are of crucial importance for the economy and vital functions of our country - these are water and forest resources. The study of legal and organizational problems of the protection of forests and waters in the Russian Federation is reflected in the works of E.V. Luneva [1], A.I., Nikiforov, M.M. Mukhlynina, O.N. Vedysheva, E.N. Redikultseva, R.F. Martynova [5], N.G. Zhavoronkova, V.B. Agafonova, G.V. Vypkhanova [6], Y.I. Shupletsova [8] and others.

\footnotetext{
* Corresponding author: muhlyninamm975@ mail.ru
} 


\section{Methods}

The methodological basis of the study was general scientific methods, so analysis and synthesis were used to study the existing theoretical and methodological approaches and provisions, as well as to conduct scientific research on the protection of forests and waters.

The informational basis of the study was made up of legal acts, documents of state authorities and their officials, scientific works of Russian scientists on the problems of improving forest protection in modern conditions $[2,3,4,7]$.

\section{Results and discussion}

One of the goals of sustainable development is to ensure the availability and rational use of water resources. By 2030, the goal is to improve water quality by reducing pollution, eliminating waste and minimizing emissions of hazardous chemicals and materials, halving the proportion of untreated wastewater, increasing recycling and safe reuse of wastewater around the world. In addition, countries should ensure integrated water resources management at all levels, including cross-border cooperation. It is necessary to increase the efficiency of water use by reducing water consumption in economic activities. Water use efficiency is one of the indicators for assessing the economic and social use of water resources in various sectors of the economy (in agriculture, production, housing and communal services, etc.).

If we turn to the experience of legal regulation and the practice of applying the water and environmental laws of the Russian Federation, we can single out the Water Strategy of the Russian Federation for the period until 2020, the Federal Program Development of the Water Management Complex of the Russian Federation in 2012-2020, the State Program of the Russian Federation in 2014 Reproduction and use of natural resources (subprogram Use of water resources) [2] and others. The presented documents highlight such problems as irrational use of water resources, water shortages in some regions of the Russian Federation, unsatisfactory quality of drinking water and limited access to centralized water supply systems.

To solve these problems and implement the SDGs in the field of water use in Russia, the following tasks are set in the strategic planning documents:

- ensuring the efficient operation of water management systems and hydraulic structures;

- ensuring the effective implementation by state authorities of the Russian Federation of the powers in the field of water relations;

- restoration and environmental rehabilitation of water bodies;

- reduction of negative anthropogenic impact on water bodies; development and modernization of the system of state monitoring of water bodies.

Forests, taking into account their global environmental significance and economic potential, are also among the priority areas of Russian state policy. According to the Strategy for the Development of the Forest Sector of the Russian Federation until 2030, one of the goals in the field of forestry is to achieve sustainable forest management, innovative and effective development of the use, conservation, protection and reproduction of forests that ensure the growth of the forest sector of the economy, social and environmental safety of the country, and the implementation of international obligations of the Russian Federation regarding forests [3]. The 1992 Rio de Janeiro Conference, which marked the beginning of sustainable development, identified 17 Sustainable Development Goals for the period up to 2030. Goal number 15 is defined as "Protecting and restoring land ecosystems and promoting their rational use, sustainable forest management, combating desertification, 
stopping and reversing the process of land degradation and ending the process of biodiversity loss" [4].

According to researchers A.I. Nikiforov, M.M. Mukhlynina, O.N. Vedysheva, E.N. Redikultseva, R.F. Martynova, the main measures for the implementation of the state policy of the Russian Federation in the field of forest use, conservation, protection and reproduction include improvement of legislation regarding state forest pathological monitoring and monitoring of forest reproduction [5], state forest supervision, and compensation for damage caused to forests and objects of nature [6] and others.

In order to streamline the use of forests, reduce illegal wood circulation, control over felling and the origin of wood and its turnover there is the Federal Law of the Russian Federation No. 415 of December 28, 2013 On Amending the Forest Code of the Russian Federation and the Code of Administrative Offenses of the Russian Federation which introduced unified state automated information system for wood accounting and transactions with it. 2019 proved that the interagency cooperation between the Federal Forestry Agency, the Federal Customs Service, the Federal Tax Service, the Ministry of Internal Affairs of Russia, Russian Financial Monitoring and other federal bodies in terms of control over the legal circulation of wood from the cutting area to processing or export is possible. Voluntary certification is an addition to the information system regarding responsible forest management and achieving sustainable development. It supports environmentally responsible, socially oriented, cost-effective forest management.

It should be noted that there are two international forest certification systems in Russia: FSC (Forest Stewardship Council) and PEFC (Pan-European Certification Scheme, since 2003 it has been renamed the Forest Certification System Approval Program). FSC certificates (forest management, supply chain, certificate of controlled wood for forest use); PEFC forest management certificates and management chains. Certification shows that during forest management all legislatively established requirements have been met. A voluntary certification system does not replace the state forest management policy, but has an impact on its formation.

Among the effective forest management mechanisms, the Federal Agency for Forestry (Rosleskhoz) maintains a register of unscrupulous tenants of forest plots and buyers of forest stands. Forest users who avoid making forest payments, systematically failing to fulfill contractual obligations regarding forestry activities, and other requirements of forest legislation are entered in such a register. For them, the possibility of access to forest resources for entrepreneurial purposes is further excluded. According to statistics, as of March 5, 2020, the register contains 531 unscrupulous forest users. The number of terminated agreements and the facts of evading the conclusion of the agreement is 803 [7].

The main types of violations of forest legislation include:

- failure to comply with forestry regulations;

- failure to implement a forest development project regarding forest reproduction;

- failure to implement a forest development project regarding the protection of forests from fires.

From inspection of lease agreements for forest plots that were provided for logging by Rosleskhoz, 3,500 violations were identified. Inspectors issue binding orders to eliminate violations on the protection, conservation and reproduction of forests, and in case of failure to apply to the court with a request for early termination of leases of forest fund plots [6].

Thus, there is a tendency to increase the registry of unscrupulous forest users.

\section{Conclusions}

To sum up, it can be noted that the Federal Forestry Agency believes that one of the possible measure of preventing violations is introducing into the duties of tenants the 
delivery of work to protect and reproduce forests only after field inspections. In order to ensure sustainable forest management, Rosleskhoz proposes to create a specialized stateowned company, endowed with economic functions and rights for the integrated use of forests. It will help to solve the problem of sustainable forest management with the involvement of extrabudgetary sources of funding and public-private partnership opportunities.

As for the legal ways to solve problems within the framework of achieving the SDGs in the field of water use, the Russian Federation actively interacts with foreign countries that have transboundary water bodies. Russia participates in intergovernmental agreements with the following countries: Abkhazia, Azerbaijan, Belarus, Kazakhstan, China, Mongolia, Finland and Estonia.

Sustainable water use is impossible without environmental protection measures being carried out domestically. For example, 4 out of 11 federal projects in the Ecology National Project were allocated on water bodies: Clean Water, Improvement of the Volga, Preservation of Lake Baikal, Preservation of Unique Water objects. These projects are aimed to improve the quality of drinking water for residents of settlements that are not equipped with modern centralized water supply systems; ecological improvement of water bodies, including the Volga River, preservation of unique water systems, including Lakes Baikal and Teletskoye.

For example, the institution providing the right to use water bodies allows to optimize water use and ensure the protection of water bodies through the terms of a water use agreement. On January 1, 2019, 111,267 permits were registered in the state water registry. In addition, the Federal Water Resources Agency (Rosvodresursy) maintains a register of dishonest water users and participants of auction for the right to conclude a water use agreement, which in practice allows to prevent the use of water bodies and resources by previously identified offenders.

We agree with the opinion of Y. I. Shupletsova, who notes that the rational use of natural resources is an important environmental problem and is one of the most acute global issue requiring urgent fundamental study and solution, but, unfortunately, there are many problems with forest industry, and for their effective solution it is necessary to adopt a large number of legal acts [8].

\section{References}

1. E.V. Luneva, Lex Russica, 12, 67 (2018)

2. Order of the Government of the Russian Federation of August 27, 2009 No. 1235-r (as amended on April 17, 2012) On Approving the Water Strategy of the Russian Federation for the Period Until 2020

3. Order of the Government of the Russian Federation of September 20, 2018 No. 1989-r (as amended on February 28, 2019) On Approving the Development Strategy of the Forestry Complex of the Russian Federation until 2030, No. 40, art . 6147 (2018)

4. The official website of the UN [Electronic resource]. URL: https: // www.un.org 5. A.I. Nikiforov, M.M. Mukhlynina, O.N. Vedysheva, E.N. Redikultceva R.F. Martynova, International Journal of Engineering and Advanced Technology, 8(5), 2251-2255 (2019)

6. N.O. Vedysheva, Problems of forest legislation and ways to improve it, 119-123 (2019)

7. The official website of Rosleskhoz [Electronic resource]. URL: https: // rosleshoz.gov.ru

8. Y.I. Shupletsova, Journal of Russian Law, 3(219), 72-29 (2015) 